• 研究报告・

\title{
气候变化和经济发展对肾综合征 出血热发生的影响
}

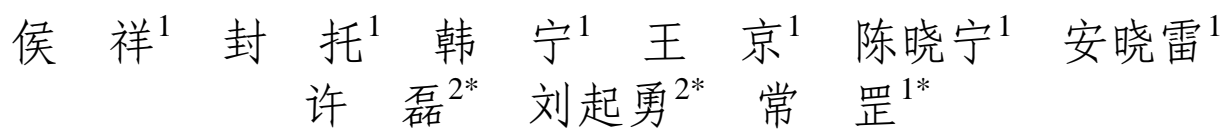

1 (陕西省动物研究所陕西省秦岭珍稀濒危动物保育重点实验室, 西安 710032)

2 (中国疾病预防控制中心传染病预防控制所传染病预防控制国家重点实验室，北京 102206)

\begin{abstract}
摘要: 肾综合征出血热(hemorrhagic fever with renal syndrome, HFRS)是一种啮齿动物传播的自然疫源性疾病, 危 害严重, 已成为全球重要的公共卫生问题。本研究采用数理统计模型及小波分析方法, 对陕西省西安市郎邑区 1984-2016年HFRS的发生与鼠类、气候和经济因素的关系进行分析，探讨气候和经济因素对HFRS发生的影响。小 波分析结果表明, 该地区的HFRS暴发史可能分为两个时期, 推测每个时期具有不同的主要宿主, 在2002年褐家鼠 (Rattus norvegicus) 可能取代黑线姬鼠(Apodemus agrarius)成为HFRS疫源地的主要宿主。广义可加模型模拟结果表 明, HFRS的发生与1984-2001年黑线姬鼠密度间存在极显著非线性效应 $\left(F_{2.06,9.02}=102.415, P<0.01\right)$, 两者间显现 为正相关; 与2002-2016年的褐家鼠密度间呈正相关 $\left(F_{1.67,9.02}=73.929, P<0.01\right)$; HFRS主要宿主的这种变化可能 与当地气候变化和经济发展有关: HFRS的发生与年平均温度存在极显著的非线性效应 $\left(F_{2.93,9.02}=12.164, P<\right.$ $0.01)$, 两者间呈负相关; 同样, HFRS的发生与上一年的国内生产总值 $(\mathrm{GDP})$ 也存在显著非线性效应 $\left(F_{1.70,9.02}=\right.$ $2.917, P<0.05)$, 两者间也呈负相关。结构方程模型通过直接和间接的影响途径证明了这种转移机制, 发现温度对 HFRS发生有显著的直接负向影响以及通过褐家鼠的间接正向影响; GDP对HFRS发生有直接的负向影响。本研究 表明HFRS的发生与气候变化和经济发展相关, 两者均能影响HFRS的暴发, 该结论有助于今后更好地对HFRS疾 病进行预防和控制。
\end{abstract}

关键词: 气候变化; 经济发展; 肾综合征出血热; 鼠类密度; 广义可加模型; 结构方程模型; 小波分析

\section{Effect of climate change and economic development on hemorrhagic fever with renal syndrome}

Xiang $\mathrm{Hou}^{1}$, Tuo Feng ${ }^{1}$, Ning $\mathrm{Han}^{1}$, Jing Wang ${ }^{1}$, Xiaoning $\mathrm{Chen}^{1}$, Xiaolei $\mathrm{An}^{1}$, Lei $\mathrm{Xu}^{2, *}$, Qiyong $\mathrm{Liu}^{2, *}$, Gang Chang ${ }^{1, *}$

1 Shaanxi Key Laboratory for Animal Conservation, Shaanxi Institute of Zoology, Xi'an 710032

2 State Key Laboratory of Infections Disease Prevention and Control, National Institute for Communicable Disease Control and Prevention, Chinese Center for Disease Control and Prevention, Beijing 102206

Abstract: Hemorrhagic fever with renal syndrome (HFRS) is a natural focus disease transmitted via contact with infected rodents and is a global public health threat. Using statistical models and wavelet analysis, we analyzed the effects that rodent density, climate and economic variations on HFRS cases in the Huyi District of Xi'an City, Shaanxi Province from 1984-2016. We found that the outbreak history could be divided into two periods, each of which with a different major reservoir. We found that Rattus norvegicus may have replaced Apodemus sagrarius as the major reservoir of HFRS around 2002, using wavelet analysis. Generalized additive models show that incidence of HFRS was positively associated with Apodemus sagrarius densities from 1984 to $2001\left(F_{2.06,9.02}=102.415, P<0.01\right)$ and with Rattus norvegicus densities

收稿日期: 2020-07-03; 接受日期: 2020-10-08

基金项目: 陕西省林业科学院科技创新计划(SXLK2020-0209)、陕西省科学院重大科学研究专项(2014K-38; 2018K-04)、陕西省重点研发计划 (2018NY-135)、陕西省科学院科技计划(2017K-11; 2020k-21)和陕西省科学院高层次人才引智计划项目(2018nk-12)

* 共同通讯作者 Co-authors for correspondence. E-mail: snow1178@snnu.edu.cn; liuqiyong@icdc.cn; xulei@icdc.cn 
from 2002 and $2016\left(F_{1.67,9.02}=73.929, P<0.01\right)$. We also found that the shift in major reservoir for HFRS was associated with local climate variation (quantified by annual average temperature), and economic activity (quantified by gross domestic product, GDP). We found negative correlations between temperature and incidence of HFRS $\left(F_{2.93,9.02}=12.164, P<0.01\right)$ and between GDP and incidence of HFRS $\left(F_{1.70,9.02}=\right.$ 2.917, $P<0.05$ ). We used a structural equation model to demonstrate this shift in reservoir through direct and indirect pathways, and found that temperature had a direct negative effect on HFRS incidence and an indirect positive effect via Rattus norvegicus. GDP has a direct negative effect on HFRS incidence. This study has demonstrated how changes in climate and economic factors have affected outbreak of HFRS. Knowledge of these effects can contribute in helping develop better strategies for controlling the spread of HFRS.

Key words: climate change; economic development; hemorrhagic fever with renal syndrome (HFRS); rodent density; generalized additive model; structural equation model; wavelet analysis

肾综合征出血热(hemorrhagic fever with renal syndrome, HFRS)是一种经啮齿动物传播的自然疫 源性疾病, 主要由鼠类携带传播的汉坦病毒 (Hantaviruses)引起, 该病毒属于布尼亚病毒科汉坦 病毒属(Hantavirus), 引起HFRS的病毒主要有汉滩 病毒(Hantaan virus, HTNV)、汉城病毒(Seoul virus, SEOV)、普马拉病毒(Puumala virus, PUUV)和多不 拉伐病毒(Dobrava virus, DOBV)等。HFRS的临床症 状主要包括发热、出血、头痛、低血压休克及肾脏 损害等(Sargianou et al, 2012)。该病的传播主要通过 接触宿主动物排泄物、伤口感染、气溶胶、被病鼠 排泄物污染的食物等途径, 还可通过媒介生物(螨 类)传播或通过母体垂直传播(Nichol et al, 1993)。近 年来, 全球汉坦病毒感染发病率呈现逐年上升的趋 势, 欧美国家尤为明显, 在美洲发现的汉坦病毒肺 综合征(Hantavirus pulmonary syndrome, HPS)是由 汉坦病毒中的辛诺柏病毒(Sin Nombre virus, SNV)、 安第斯病毒(Andes virus, ANDV)引起, 具有高致病 性、高传染性及高致死率的特点。HFRS和HPS的死 亡率分别为 $12 \%$ 和 $60 \%$, 遍及世界各大洲, HFRS主 要分布于欧亚大陆, HPS 主要分布于美洲大陆 (Kariwa et al, 2007; Tian et al, 2017b)。

我国是受HFRS影响最为严重的国家, 在全国 34 个省、自治区、直辖市、特别行政区中, 31个均 有该病例报告(Watson et al, 2014; Xiao et al, 2015)。 陕西省是受HFRS危害较严重的省份之一, 发病数 一直居全国前列(Liang et al, 2018)。陕西省西安市 一直是HFRS 高发疫区, 发病率占陕西省的 $90 \%$ 以 上, 主要集中在㲅邑区、长安区及周至县(Xiao et al, 2015; Tian et al, 2017b)。㲅邑区于1956年报告首例
HFRS 病例, 20 世纪 80 年代该地区发病急剧上升 (Xiao et al, 2015)。

影响HFRS的因素较多, 如气候、社会经济(如 国内生产总值(GDP)、人口密度、粮食产量)、生态 环境(啮齿动物种群数量) (Xiao et al, 2013a)、啮齿动 物病毒携带率(Li et al, 2014)等。气候因素通过影响 病毒的感染率、宿主动物的种群密度以及人类与宿 主动物的接触率而影响HFRS的发生(McMichael et al, 2006; Tian et al, 2017b), 其中温度和降水是影响 HFRS的最重要因素之一(Xiao et al, 2013b; Tian et al, 2017b)。研究发现, 在西欧, 汉坦病毒感染堤岸 田鼠(Myodes glareolus)引发的鼠传性疾病暴发与当 地平均温度的升高正相关(Clement et al, 2009)。在 北美, 大量降雨后草场产量的增加与拉布拉多白足 鼠(Peromyscus maniculatus)种群数量的增加有关, 该鼠携带的辛诺柏病毒可引发疾病发生 (Engelthaler et al, 1999)。然而, 在中国中部的渭河 平原, HFRS发病率与夏季气温呈较强的负相关, 而 与夏季降水呈正相关(Tian et al, 2017b)。在中国的东 北地区, 大量的降水破坏了鼠类的栖息环境，降低 了HFRS的发生(Bi et al, 2002)。除气候因素外, 经济 活动的增加会改变当地主要宿主的种群结构及栖 息环境, 啮齿动物的数量可能会减少 (张美文等, 2003)。鼠类可直接引起HFRS的发生, 通过增加与 人类的接触几率进行传播(Kallio et al, 2009; Tian et al, 2017b)。此外, 经济发展改善了人类生活条件和 居住环境, 促进自我保护意识的提升, 导致当地主 要宿主种群结构和 HFRS 疾病传播发生变化 (Habtemariam et al, 2017)。同时, 经济发展可能会增 加其他病毒性疾病(如流感、肠胃炎和水痘等)的传 
播率(Adda, 2016)。随着全球气候变化和经济发展的 加速, 啮齿动物的分布和种群密度可能会发生变化 (Bayram et al, 2017), 从而可能会导致鼠传性疾病 的暴发, 已有大量研究关注气候变化如何影响 HFRS 的暴发(McMichael et al, 2006; Xiao et al, 2013b; Tian et al, 2017b)。然而, 关于经济发展如何 影响HFRS发生的报道较少(Xiao et al, 2014b; Tian et al, 2018), 仍需要进一步的研究。

以往关于HFRS发生的研究主要关注HFRS年 际间的变化与外部因素(如气候和鼠类密度)的关系 (Tian et al, 2015, 2017a, b), 在此基础上, 我们继续 分析了HFRS的流行病学特征, 并从生态、经济和气 候因素三个方面对HFRS的发生进行研究。本文通 过模型拟合和小波分析，分析了1984-2016年陕西 省西安市㲅邑区气候变化和经济发展对HFRS发生 所起的作用，拟探讨气候变化、经济发展、鼠类种 群密度与HFRS之间的关系, 评估气候变化和经济 发展对HFRS的影响, 从而为疾病防控提供依据。

\section{材料与方法}

\section{1 研究地点}

本研究选择陕西省西安市㲅邑区 $\left(108^{\circ} 22^{\prime}-108^{\circ} 46^{\prime} \mathrm{E}, 33^{\circ} 46^{\prime}-34^{\circ} 16^{\prime} \mathrm{N}, 1,282 \mathrm{~km}^{2}\right)$ 。该 地区处于关中平原中部, 是HFRS高发疫区, 野外 优势鼠种是黑线姬鼠(Apodemus agrarius), 携带汉 滩病毒, 居住区优势鼠种是褐家鼠(Rattus

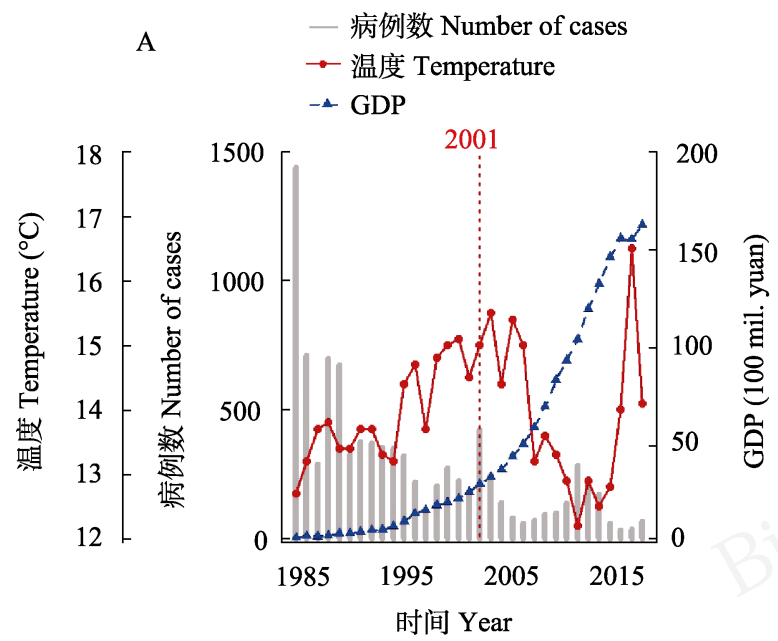

norvegicus), 携带汉城病毒, 两种病毒在研究区均 有存在并均可引起 HFRS 发生(Xiao et al，2015; Zhang et al, 2010), 其中汉滩病毒感染较为普遍 (Xiao et al, 2014a; Tian et al, 2017a)。

\section{2 疾病监测与鼠类种群监测资料}

1984-2016年HFRS疾病监测资料和鼠类种群 监测资料均来源于中国疾病预防控制中心传染病 预防控制所(图1)。疾病监测资料中收集的HFRS数 据为年际病例数, 鼠类的年际种群密度近似以捕获 率计算, 捕获率 $(\%)=($ 捕鼠只数 $/$ 夹总数 $) \times 100 \%$ 。

\section{3 气象和经济资料}

年平均气温(图1)、年降水量等数据均来自于国 家气象信息中心(http://data.cma.cn/site/index.html)。 采用距离该研究地区最近的气象站数据进行匹配。 经济指标中的人口数量(万人)、国内生产总值(GDP, 亿元)(图1)、粮食产量(万吨)、耕地面积(万公顷)等 数据均来自于㲅邑区统计年鉴。

\section{4 研究方法}

\subsection{1 小波分析}

利用小波分析方法研究了生态因子与疾病发 生时间序列之间的相关性(Zhang et al, 2009; Tian et al, 2017b)。利用R软件(V3.3.3)的“biwavelet”软件包 进行双变量小波分析来研究鼠类种群密度与HFRS 发生的周期性和相关性。

\subsection{2 广义可加模型}

广义可加模型(generalized additive models,

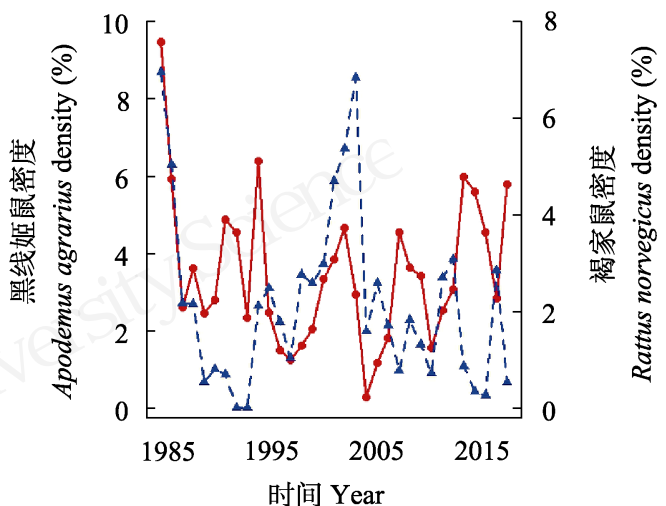

图1 1984-2016年陕西省西安市漂邑区肾综合征出血热(HFRS)病例数、温度、国内生产总值(GDP)及鼠密度时间序列图 Fig. 1 Yearly time series of cases of hemorrhagic fever with renal syndrome (HFRS), temperature, gross domestic product (GDP) and rodent density in the Huyi District of Xi'an City, Shaanxi Province from 1984 to 2016 
GAM)是一种非线性统计模型(Wood, 2006; 侯祥等, 2019)。采用广义可加模型作为数理统计分析方法, 可以发现疾病发生与生态因子、环境变量间的复杂 非线性关系。建立以HFRS为响应变量的模型, 分析 响应变量和黑线姬鼠密度、褐家鼠密度、气温(年平 均温度)、GDP、人口、耕地、粮食产量间的非线性 关系。使用 R软件(V3.3.3)的“mgcv”软件包(1.8-12) 完成。以广义交互验证指数 (generalized cross validation, GCV)和赤池信息准则(akaike information criterion, AIC) 作为篮选参数, GCV 和AIC 值越低, 模型越优，拟合越好(Stige et al, 2006; Wood, 2006)。 分别对篮选后的模型进行残差分析，通过检验时间 序列上残差的自相关性作为判定模型优劣的重要 标准(Xu et al, 2011)。在最初的模型中加入时间平滑 函数。模型采用广义可加模型中的高斯分布进行分 析, 为了使响应变量更接近于正态分布, 对该变量 进行对数转化(log-transformed)。经过模型篎选, 得 到最优模型方程如下:

$$
\begin{aligned}
& \log \left(\text { HFRS }_{\mathrm{i}}\right)=a+\mathrm{f}_{1}\left(\log \text { Roednt }_{\mathrm{i} \leq 2001}^{\mathrm{w}}\right)+ \\
& \mathrm{f}_{2}\left(\log \text { Roednt }_{\mathrm{i}>2001}^{\mathrm{r}}\right)+\mathrm{f}_{3}\left(\text { Temp }_{\mathrm{i}}\right)+\mathrm{f}_{4}\left(\log G D P_{\mathrm{i}-1}\right)+\varepsilon_{\mathrm{i}}
\end{aligned}
$$

该模型为鼠密度变量的分段模型, 其中鼠密度 在1984-2001年为黑线姬鼠密度，在2002-2016年为 褐家鼠密度, 而HFRS、温度和GDP为1984-2016年 数据。变量 $H F R S_{\mathrm{i}}$ 是第 $\mathrm{i}$ 年研究区域的HFRS病例数; $a$ 为模型截距; Rodent ${ }_{\mathrm{i}}^{\mathrm{w}}$ 为研究区域第 $\mathrm{i}$ 年 $(\mathrm{i} \leq 2001)$ 野
外优势鼠种黑线姬鼠密度; Rodent $\mathrm{t}_{\mathrm{i}}^{\mathrm{r}}$ 为研究区域第 $\mathrm{i}$ 年 (i > 2001)居住区优势鼠种褐家鼠密度; Temp 表示 研究区域第 $\mathrm{i}$ 年的平均气温; $G D P_{\mathrm{i}-1}$ 表示研究区域第 $\mathrm{i}-1$ 年GDP; $\mathrm{f}_{1} 、 \mathrm{f}_{2} 、 \mathrm{f}_{3} 、 \mathrm{f}_{4}$ 是自然样条平滑函数; $\mathrm{f}_{1}$ 、 $\mathrm{f}_{2} 、 \mathrm{f}_{4}$ 中的自由度knot设置为 $3, \mathrm{f}_{3}$ 中的自由度knot设 置为 $4 ; \varepsilon_{\mathrm{i}}$ 是随机误差项。

\subsection{3 结构方程模型}

结构方程模型(structural equation model, SEM) 可以分析多变量之间的结构性关系(Steiger, 1990; Yan \& Yang, 2018)。利用结构方程模型分析HFRS、 气候因子(年平均气温)、社会经济因子(GDP，对数 转化)、生态因子(黑线姬鼠、褐家鼠, 对数转化)之 间的结构性关系。将气候和经济因素对HFRS的影 响分为直接影响和由生态因子介导的间接影响。同 时，在模型中评估各因素之间的相关性。使用 $\mathrm{R}$ 软件 (V3.3.3)的“lavaan”软件包(Rosseel, 2012)完成，以近 似误差均方根 (root mean square error of approximation, RMSEA) 和比较拟合指数 (comparative fit index, CFI) 作为模型的篮选参数, RMSEA值越小越好, CFI的取值范围为 $0-1$, 其值越 大越好(Yan \& Yang, 2018)。

\section{2 结果}

\subsection{HFRS与生态因子间时间序列的相关性}

小波分析结果发现，1984-2001年黑线姬鼠和 褐家鼠种群密度之间存在小波相关性(图2A), 并且
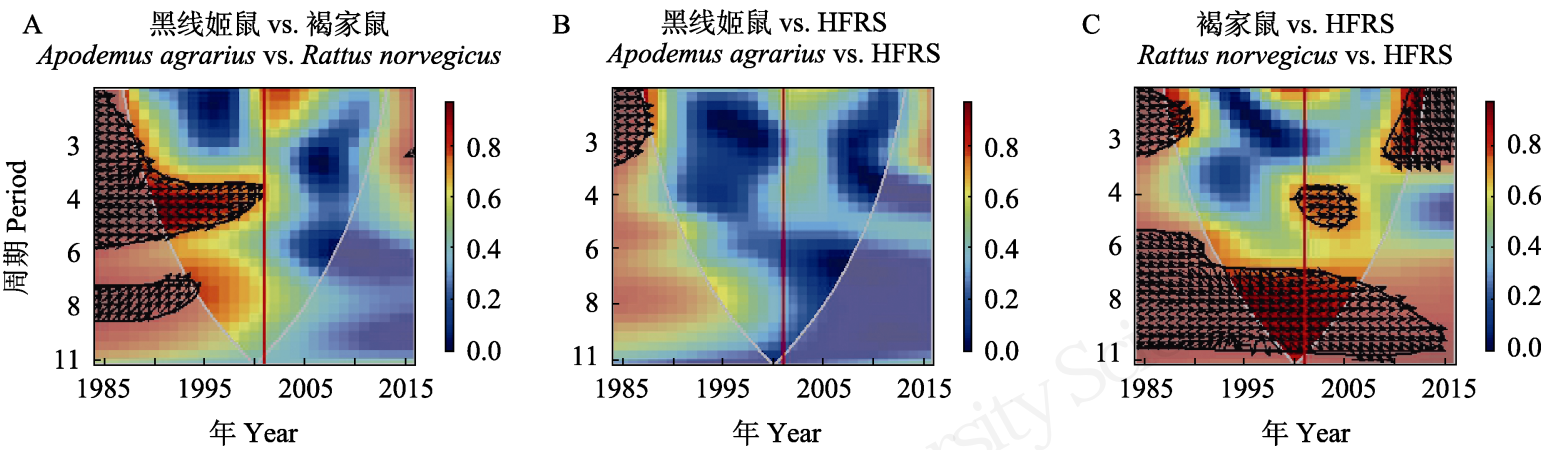

图2 黑线姬鼠密度、褐家鼠密度和肾综合征出血热(HFRS)之间的小波相关性。箭头方向代表两者间周期同步性关系，箭头 指向右代表两者处于同一周期; 箭头指向左代表两者处于不同周期; 箭头指向上代表后者领先于前者 $1 / 2$ 周期; 箭头指向下 代表后者落后于前者 $1 / 2$ 周期; 箭头存在区域代表 $P<0.05$ 显著性水平，颜色代表相关性系数。

Fig. 2 Wavelet coherence between the density of Apodemus agrarius and Rattus norvegicus and hemorrhagic fever with renal syndrome (HFRS) cases. Arrows' direction indicates periodic synchronicity between the former and the latter, arrows pointing to the right mean that the former and the latter are in phase; arrows pointing to the left mean that the former and the latter are in anti-phase; arrows pointing up mean that the latter leads the former by $\pi / 2$; arrows pointing down mean that the former leads the latter by $\pi / 2$; $\pi / 2$ indicates half of the period; arrows' region indicates significance levels $P<0.05$, color indicates the coefficient of coherence. 
HFRS 与鼠类种群密度之间也存在小波相关性, 2001年以前HFRS与黑线姬鼠种群密度存在小波相 关性(图2B), 1984-2016年间, HFRS与褐家鼠种群密 度之间存在小波相关性(图2C)。因此, HFRS的发生 历史可分为两个时期, 分别存在不同的宿主动物: 1981-2001年间, 黑线姬鼠为 HFRS 的主要宿主; 2002年开始, 褐家鼠取代黑线姬鼠成为主要宿主。

\section{2 生态环境因素对HFRS发生的影响}

在广义可加模型中, 根据GCV和AIC值越低模 型越优的标准, 选择了GCV和AIC值最低的模型(分 别为 0.144 和 28.61), 同时检测了时间序列残差的自 相关性，发现模型不具有明显的自相关性，拟合的 最优模型为分段模型，反映了1984-2001年黑线姬
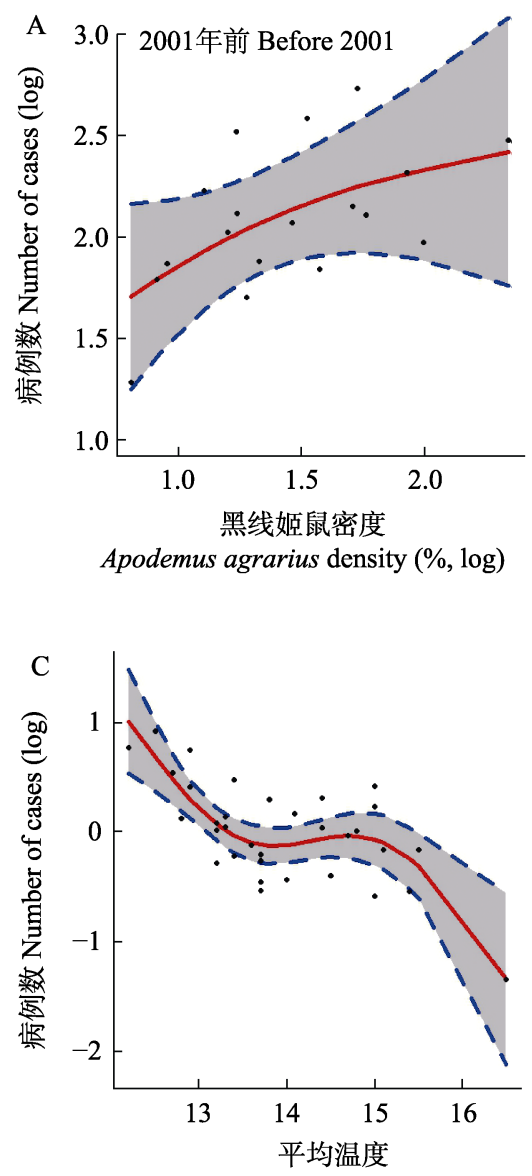

Average temperature $\left({ }^{\circ} \mathrm{C}\right)$
鼠和2002-2016年褐家鼠对HFRS的动态变化。结果 发现，鼠类对HFRS的分段效应可能与当地气候变 化(年平均气温)和经济发展(GDP)有关。该模型结果 显示, 在鼠类种群密度方面, HFRS与1984-2001年 黑线姬鼠密度间存在非线性效应 $\left(F_{2.06,9.02}=102.415\right.$, $P<0.01$; 图 3A), 两者间表现为正相关; 与 2002-2016年的褐家鼠密度间呈现正相关 $\left(F_{1.67,9.02}=\right.$ 73.929, $P<0.01$; 图3B)。在气候因素方面, HFRS与 温度间存在极显著的非线性效应 $\left(F_{2.93,9.02}=12.164\right.$, $P<0.01$; 图3C), 两者间呈现负相关。在经济发展 方面, HFRS与上一年的GDP间存在显著非线性效 应 $\left(F_{1.70,9.02}=2.917, P<0.05 ;\right.$ 图3D $)$, 两者间呈现负 相关。
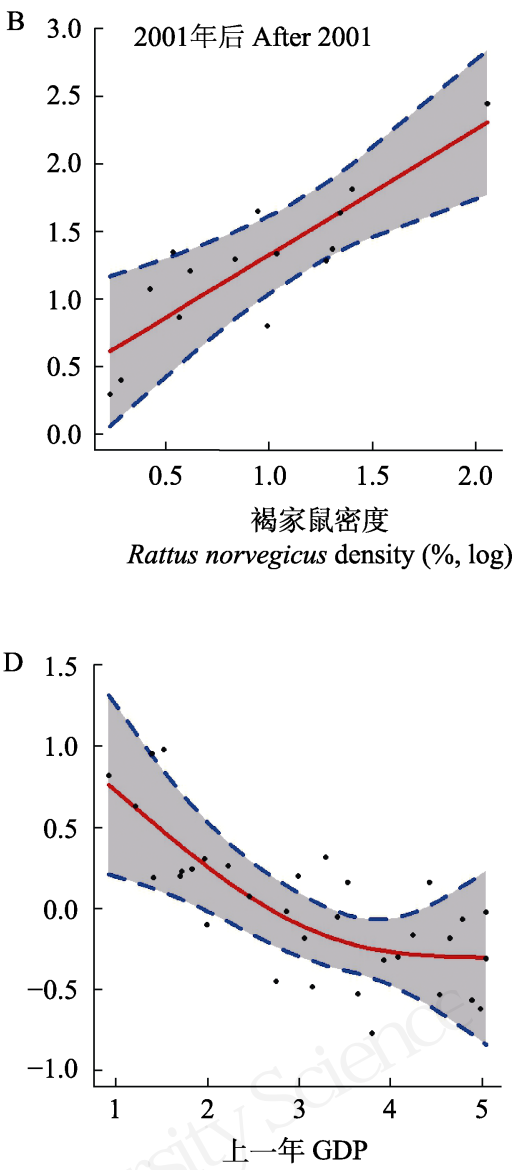

Last year GDP (100 mil.yuan, log)

图3 利用广义可加模型分析鼠密度、气候及经济因素对肾综合征出血热(HFRS)发生的影响效应(灰色区域为 $95 \%$ 置信区 间)。(A) 1984-2001年黑线姬鼠密度对HFRS发生的影响效应; (B) 2002-2016年褐家鼠密度对HFRS发生的影响效应; (C)当年 平均温度对HFRS发生的影响效应; (D)上一年当地国内生产总值(GDP)对HFRS发生的影响效应。

Fig. 3 The effects of rodent density, climate and economic factors on the cases of hemorrhagic fever with renal syndrome (HFRS) by generalized additive models (Shaded areas are 95\% confidence bands). (A) The effects of Apodemus agrarius density on the cases of HFRS from 1984-2001; (B) The effects of Rattus norvegicus density on the cases of HFRS from 2002-2016; (C)The effects of annual average temperature on the cases of HFRS; (D) The effects of local gross domestic product (GDP) in previous year on the cases of HFRS. 


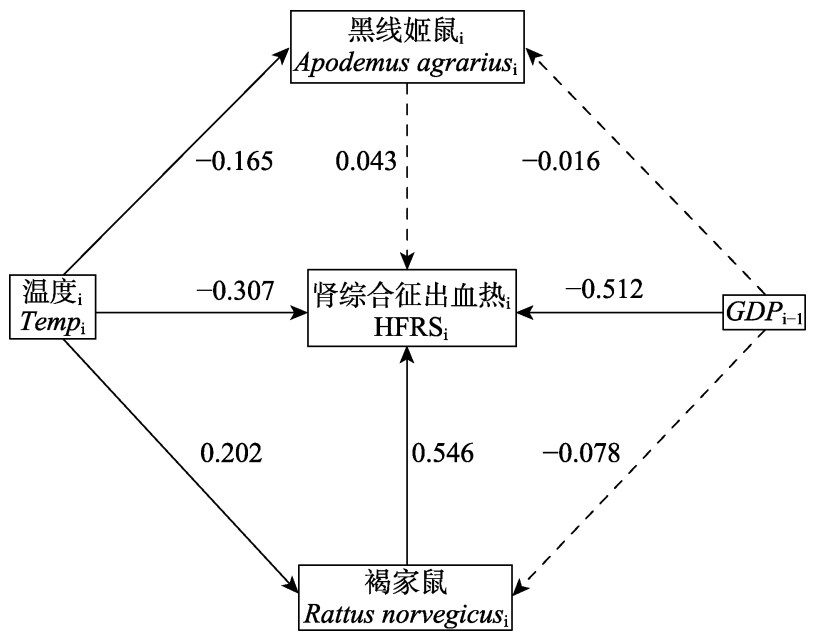

图4 利用结构方程模型分析气候和经济因素对肾综合征出 血热(HFRS)发生的直接和间接影响路径。数字代表生态效 应和相关性系数, 黑色实线代表 $P<0.05$ 的通路, 黑色虚线 代表 $\boldsymbol{P}>\mathbf{0 . 0 5}$ 的通路。

Fig. 4 Structural equation model analysis revealed direct and indirect climatic and economic effects on hemorrhagic fever with renal syndrome (HFRS) cases. Numbers indicate ecological effects and standardized coefficients, black solid line indicates statistically significant levels $P<0.05$ pathways, and black dash line indicates statistically no significant levels $P>$ 0.05 pathways.

\subsection{HFRS发生的直接和间接影响途径}

结构方程模型结果表明, 褐家鼠对 HFRS 有显 著直接的正向影响; 温度对 HFRS 有显著直接的负 向影响以及通过褐家鼠的显著间接正向影响; GDP 对 HFRS 有显著直接的负向影响(图 4) $(P=0.228$, $\mathrm{df}=1, \chi^{2}=7.58$, RMSEA $=0.132$, CFI $\left.=0.990\right)$ 。

\section{3 讨论}

在本研究中, 我们采用数理统计模型及小波分 析方法, 利用研究地区33年的HFRS发生与环境因 素(包括温度、黑线姬鼠密度、褐家鼠密度、人口数 量、粮食产量、耕地面积、GDP)数据, 研究了环境 及鼠类因素对HFRS发生的影响效应。结果表明, 1984-2016年我国西安㲅邑地区的HFRS暴发历史 可分为两个时期，分别存在不同的宿主动物。2002 年开始, 褐家鼠取代黑线姬鼠成为HFRS的主要宿 主。此外, 我们发现HFRS自然疫源地的这种变化与 当地气候变化(温度)和经济发展(GDP)有关。同时我 们还采用结构方程模型通过直接和间接的影响途 径证明了这种转移机制。

\section{1 鼠密度越高HFRS发病数越高}

研究结果表明, HFRS的发病数1984-2001年与 黑线姬鼠密度、2002-2016年与褐家鼠密度存在显 著的正相关，鼠类种群密度越高HFRS发病数越高。 这一结果与前人的研究相一致(Al-Shorbaji et al, 2016; Tian et al, 2017a, b)。通过结构方程模型分析 HFRS-鼠类之间的结构关系, 发现鼠类种群密度对 HFRS 有直接的正向影响, 褐家鼠对HFRS有显著直 接的正向影响，而黑线姬鼠没有显著影响，可能原 因是黑线姬鼠在广义可加模型中的非线性效应或 在整个周期上作用变弱。有研究表明，啮齿动物的 活动在HFRS传播中起着重要作用, HFRS主要通过 携带汉坦病毒的啮齿动物排泄物的气溶胶传播 (Tian et al, 2015, 2017b)。我国大部分野外环境条件 适合鼠类生存繁殖, 鼠类密度较高(张美文等, 2003)。人们在野外会不经意地接触啮齿动物, 容易 感染HFRS。在居住区，人们更加容易接触鼠类排泄 物而导致感染HFRS(张美文等, 2003; Bai et al, 2015)。大量研究表明, HFRS与黑线姬鼠和褐家鼠密 度存在显著正相关(Xiao et al, 2013a; Tian et al, 2015, 2017b), 这与本文的结果相一致, 但鼠密度低于 $1 \%$ 时可控制HFRS的传播(Bai et al, 2015)。

\subsection{HFRS的自然疫源地从姬鼠型转变成家鼠型}

本研究的主要发现为HFRS的自然疫源地可能 从姬鼠型转变成家鼠型。小波分析结果表明, HFRS 暴发历史可能分为两个时期，存在不同的宿主动 物。1984-2001年, 黑线姬鼠对HFRS影响较大, 为 主要的宿主动物; 而2002-2016年, 褐家鼠为主要 的宿主动物。2002年开始, 褐家鼠取代黑线姬鼠成 为HFRS的主要宿主, 表明HFRS自然疫源地类型之 间可能存在相互转换现象。因此, 我们采用广义可 加模型拟合分段模型，揭示1984-2001年黑线姬鼠 与2002-2016年褐家鼠分别对HFRS的影响效应。结 果发现, 疫源地类型的进化可能与当地气候变化 (温度)和经济发展(GDP) 有关, 温度和GDP均对 HFRS发生具有负向影响。此外, 采用结构方程模型 通过直接和间接的影响途径证明了这种转变机制: 温度对HFRS有显著的直接负向影响，还通过直接 影响鼠类种群密度间接地对HFRS有显著的正向影 响; 而GDP对HFRS有显著的直接负向影响。同时, 我们发现研究地区的GDP从2001年以后快速增长, 
这可能推动了 HFRS疫源地从姬鼠型向家鼠型的转 变。经济增长可改善人类居住环境, 改变鼠类栖息 地生境, 导致其种群密度及结构发生变化(Sun et al, 2016)。此外, 温度会影响鼠类种群数量波动及地理 分布, 因为鼠类更喜欢温暖的地区(Ge et al, 2016)。

\section{3 温度影响HFRS的发生}

温度通过影响宿主动物种群密度及人类与鼠 类之间的接触率来影响 HFRS 的发生(Xiao et al, 2015; Tian et al, 2015, 2017b)。本研究中, 广义可加 模型分析结果表明, HFRS与温度存在显著的非线 性效应，总体呈现负相关; 结构方程模型分析结果 显示, 温度对HFRS具有双重影响效应，这可能是 因为温度与HFRS存在非线性效应。总的来说, 温度 对HFRS的发生是负向影响。温度可影响鼠类繁殖 率、产仔数、存活率及病毒的传播(Ge et al, 2016)。 当温度处于 $10-25^{\circ} \mathrm{C}$ 之间, 鼠类的繁殖率最高, 温 度过高或过低均会抑制鼠类的繁殖。户外活动或工 作均会增加人与鼠类接触的机会, 而人们在户外活 动和工作时的最佳温度为 $17^{\circ} \mathrm{C}$ (Lin et al, 2014), 温 度过高或过低会减少人们户外活动和工作时间, 从 而减少与鼠类接触的机会, 降低HFRS发生。有研究 发现, HFRS的发生与温度呈负相关(Liu et al, 2011; Tian et al, 2017b), 也有一些研究表明HFRS与温度 间呈正相关(Guan et al, 2009; Wang et al, 2015), 这 种差异可能是由研究区域的环境和气候、鼠类组成 的差异或病毒血清型的差异所导致。随着全球气候 变暖, 重要病媒传播疾病的传播时间可能会延长, 其地理分布范围也将会发生变化(Pinkerton \& Rom, 2014)。可见, 全球气候变化将持续影响鼠传性疾病 的发生。

\section{4 经济发展影响HFRS的发生}

大量研究表明, 经济发展(如城镇化建设、人口 迁徙等)能够改善人类居住环境及提升自我保护意 识, 同时也可改变鼠类群落结构、种群数量及栖息 环境，使HFRS发生机制有所变化(Xiao et al, 2014b; Sun et al, 2016; Tian et al, 2018)。本研究结果表明, 经济发展直接影响HFRS发生。广义可加模型分析 发现, HFRS与当地GDP存在非线性效应, 呈现负相 关。同时, 结构方程模型结果显示, GDP直接驱动并 负向影响HFRS。有研究发现, HFRS的发生随当地 GDP的升高而下降(Xiao et al, 2014b)。城市化、城
镇化引起的生态环境的改变会对鼠类生存条件和 食物来源产生直接或间接的影响，从而导致鼠类种 群密度、种群结构及HFRS疾病传播的改变(张美文 等, 2003; Habtemariam et al, 2017)。此外, 经济快速 发展, 城市卫生环境大大改善, 人们在城市与鼠类 接触的几率远远低于农村地区。大量农村人口迁移 到城市可能是HFRS逐年下降的原因之一。经济的 快速增长进一步改善了临床基础设施并提高了人 们对疾病预防控制的认知能力，也有助于降低 HFRS疾病的发生。

本研究结果表明, 2002年开始, HFRS自然疫源 地发生了变化, 而这种变化可能与当地气候变化 (温度)和经济发展(GDP)有关, 气候变化和经济发 展(GDP)对HFRS发生具有显著的影响。

\section{参考文献}

Adda J (2016) Economic activity and the spread of viral diseases: Evidence from high frequency data. The Quarterly Journal of Economics, 131, 891-941.

Al-Shorbaji F, Roche B, Gozlan R, Britton R, Andreou D (2016) The consequences of reservoir host eradication on disease epidemiology in animal communities. Emerging Microbes and Infections, 5, e46.

Bai YT, Xu ZG, Lu B, Sun QH, Tang WG, Liu XB, Yang WZ, Xu XY, Liu QY (2015) Effects of climate and rodent factors on hemorrhagic fever with renal syndrome in Chongqing, China, 1997-2008. PLoS ONE, 10, e0133218.

Bayram H, Bauer AK, Abdalati W, Carlsten C, Pinkerton KE, Thurston GD, Balmes JR, Takaro TK (2017) Environment, global climate change, and cardiopulmonary health. American Journal of Respiratory and Critical Care Medicine, 195, 718-724.

Bi P, Tong S, Donald K, Parton K, Ni J (2002) Climatic, reservoir and occupational variables and the transmission of haemorrhagic fever with renal syndrome in China. International Journal of Epidemiology, 31, 189-193.

Clement J, Vercauteren J, Verstraeten WW, Ducoffre G, Barrios JM, Vandamme AM, Maes P, Ranst MV (2009) Relating increasing Hantavirus incidences to the changing climate: The mast connection. International Journal of Health Geographics, 8, 1-11.

Engelthaler DM, Mosley DG, Cheek JE, Levy CE, Komatsu KK, Ettestad P, Davis T, Tanda DT, Miller L, Frampton JW, Porter R, Bryan RT (1999) Climatic and environmental patterns associated with Hantavirus pulmonary syndrome, Four Corners region, United States. Emerging Infectious Diseases, 5, 87-94.

Ge L, Zhao YL, Zhou K, Mu XM, Yu HB, Wang YF, Ning W, 
Hong F, Guo LQ, Huo XX (2016) Spatio-temporal pattern and influencing factors of hemorrhagic fever with renal syndrome (HFRS) in Hubei Province (China) between 2005 and 2014. PLoS ONE, 11, e0167836.

Guan P, Huang DS, He M, Shen TF, Guo JQ, Zhou BS (2009) Investigating the effects of climatic variables and reservoir on the incidence of hemorrhagic fever with renal syndrome in Huludao City, China: A 17-year data analysis based on structure equation model. BMC Infectious Diseases, 9, 109.

Habtemariam LT, Kassa GA, Gandorfer M (2017) Impact of climate change on farms in smallholder farming systems: Yield impacts, economic implications and distributional effects. Agricultural Systems, 152, 58-66.

Hou X, Liu KK, Liu XB, Chang G, Xu L, Liu QY (2019) Nonlinear effects of climate factors on dengue epidemic in Guangdong Province, China. Chinese Journal of Vector Biology and Control, 30, 25-30. (in Chinese with English abstract) [侯祥, 刘可可, 刘小波, 常罡, 许磊, 刘起勇 (2019) 气候因素对广东省登革热流行影响的非线性效 应. 中国媒介生物学及控制杂志, 30, 25-30.]

Kallio ER, Begon M, Henttonen H, Koskela E, Mappes T, Vaheri A, Vapalahti O (2009) Cyclic Hantavirus epidemics in humans-predicted by rodent host dynamics. Epidemics, 1, 101-107.

Kariwa H, Yoshimatsu K, Arikawa J (2007) Hantavirus infection in East Asia. Comparative Immunology Microbiology and Infectious Diseases, 30, 341-356.

Li Q, Zhao WN, Wei YM, Han X, Han ZY, Zhang YB, Qi SX, Xu YG (2014) Analysis of incidence and related factors of hemorrhagic fever with renal syndrome in Hebei Province, China. PLoS ONE, 9, e101348.

Liang WF, Gu X, Li X, Zhang KJ, Wu KJ, Pang MM, Dong JH, Merrill HR, Hu T, Liu K (2018) Mapping the epidemic changes and risks of hemorrhagic fever with renal syndrome in Shaanxi Province, China, 2005-2016. Scientific Reports, 8, 749.

Lin HL, Zhang ZT, Lu L, Liu QY (2014) Meteorological factors are associated with hemorrhagic fever with renal syndrome in Jiaonan County, China, 2006-2011. International Journal of Biometeorology, 58, 1031-1037.

Liu XD, Jiang BF, Gu WD, Liu QY (2011) Temporal trend and climate factors of hemorrhagic fever with renal syndrome epidemic in Shenyang City, China. BMC Infectious Diseases, 11, 331.

McMichael AJ, Woodruff RE, Hales S (2006) Climate change and human health: Present and future risks. Lancet, 367, 859-869.

Nichol ST, Spiropoulou C, Morzunov S, Rollin PE, Ksiazek TG, Feldmann H, Sanchez A, Childs J, Zaki S, Peters C (1993) Genetic identification of a Hantavirus associated with an outbreak of acute respiratory illness. Science, 262, 914-917.

Pinkerton KE, Rom WN (2014) Global Climate Change and
Public Health. Springer, London.

Rosseel Y (2012) lavaan: An R package for structural equation modeling. Journal of Statistical Software, 48, 1-36.

Sargianou M, Watson DC, Chra P, Papa A, Panos G (2012) Hantavirus infections for the clinician: From case presentation to diagnosis and treatment. Critical Reviews in Microbiology, 38, 317-329.

Steiger JH (1990) Structural model evaluation and modification: An interval estimation approach. Multivariate Behavioral Research, 25, 173-180.

Stige LC, Ottersen G, Brander K, Chan KS, Stenseth NC (2006) Cod and climate: Effect of the North Atlantic Oscillation on recruitment in the North Atlantic. Marine Ecology Progress Series, 325, 227-241.

Sun J, Wang JN, Wei YQ, Li YR, Liu M (2016) The haze nightmare following the economic boom in China: Dilemma and tradeoffs. International Journal of Environmental Research and Public Health, 13, 1-12.

Tian HY, Hu SX, Cazelles B, Chowell G, Gao LD, Laine M, Li YP, Yang HS, Li YD, Yang QQ, Tong X, Huang R, Bjornstad ON, Xiao H, Stenseth NC (2018) Urbanization prolongs Hantavirus epidemics in cities. Proceedings of the National Academy of Sciences, USA, 115, 4707-4712.

Tian HY, Yu PB, Bjørnstad ON, Cazelles B, Yang J, Tan H, Huang SQ, Cui YJ, Dong L, Ma CF, Ma CA, Zhou S, Laine M, Wu XX, Zhang YY, Wang JJ, Yang RF, Stenseth NC, $\mathrm{Xu}$ B (2017a) Anthropogenically driven environmental changes shift the ecological dynamics of hemorrhagic fever with renal syndrome. PLoS Pathogens, 13, e1006198.

Tian HY, Yu PB, Cazelles B, Xu L, Tan H, Yang J, Huang SQ, Xu B, Cai J, Ma CF, Wei J, Li S, Qu JH, Laine M, Wang JJ, Tong SL, Stenseth NC, Xu B (2017b) Interannual cycles of Hantaan virus outbreaks at the human-animal interface in Central China are controlled by temperature and rainfall. Proceedings of the National Academy of Sciences, USA, 114, 8041-8046.

Tian HY, Yu PB, Luis AD, Bi P, Cazelles B, Laine M, Huang SQ, Ma CF, Zhou S, Wei J, Li S, Lu XL, Qu JH, Dong JH, Tong SL, Wang JJ, Grenfell B, Xu B (2015) Changes in rodent abundance and weather conditions potentially drive hemorrhagic fever with renal syndrome outbreaks in Xi'an, China, 2005-2012. PLOS Neglected Tropical Diseases, 9, e0003530.

Wang T, Zhou YP, Wang L, Huang ZS, Cui F, Zhai SY (2015) Using autoregressive integrated moving average model to predict the incidence of hemorrhagic fever with renal syndrome in Zibo, China, 2004-2014. Japanese Journal of Infectious Diseases, 69, 279-284.

Watson DC, Sargianou M, Papa A, Chra P, Starakis I, Panos G (2014) Epidemiology of Hantavirus infections in humans: A comprehensive, global overview. Critical Reviews in Microbiology, 40, 261-272.

Wood SN (2006) Generalized Additive Models: An 
Introduction with R. Chapman \& Hall/CRC, Boca Raton.

Xiao D, Wu KJ, Tan X, Le J, Li HT, Yan YP, Xu ZK (2015) Modeling and predicting hemorrhagic fever with renal syndrome trends based on meteorological factors in $\mathrm{Hu}$ County, China. PLoS ONE, 10, e0123166.

Xiao D, Wu KJ, Tan X, Yan TC, Li HT, Yan YP (2014a) The impact of the vaccination program for hemorrhagic fever with renal syndrome in $\mathrm{Hu}$ County, China. Vaccine, 32, 740-745.

Xiao H, Tian HY, Gao LD, Liu HN, Duan LS, Basta N, Cazelles B, Li XJ, Lin XL, Wu HW, Chen BY, Yang HS, Xu B, Grenfell B (2014b) Animal reservoir, natural and socioeconomic variations and the transmission of hemorrhagic fever with renal syndrome in Chenzhou, China, 2006-2010. PLoS Neglected Tropical Diseases, 8, e2615.

Xiao H, Gao LD, Li XJ, Lin XL, Dai XY, Zhu PJ, Chen BY, Zhang XX, Zhao J, Tian HY (2013a) Environmental variability and the transmission of haemorrhagic fever with renal syndrome in Changsha, People's Republic of China. Epidemiology and Infection, 141, 1867-1875.

Xiao H, Tian HY, Cazelles B, Li XJ, Tong SL, Gao LD, Qin JX, Lin XL, Liu HN, Zhang XX (2013b) Atmospheric moisture variability and transmission of hemorrhagic fever with renal syndrome in Changsha City, Mainland China, 1991-2010. PLoS Neglected Tropical Diseases, 7, e2260.

Xu L, Liu QY, Stige LC, Ari TB, Fang XY, Chan KS, Wang
SC, Stenseth NC, Zhang ZB (2011) Nonlinear effect of climate on plague during the third pandemic in China. Proceedings of the National Academy of Sciences, USA, 108, 10214-10219.

Yan X, Yang YY (2018) RMSEA, CFI, and TLI in structural equation modeling with ordered categorical data: The story they tell depends on the estimation methods. Behavior Research Methods, 51, 409-428.

Zhang MW, Wang Y, Li B, Chen AG (2003) The rodent pest control of the social-economical-natural complex ecosystem. Acta Theriologica Sinica, 23, 250-258. (in Chinese with English abstract) [张美文, 王勇, 李波, 陈安 国 (2003) “社会-经济-自然复合生态系统”中的鼠害治 理. 兽类学报, 23, 250-258.]

Zhang YZ, Zou Y, Fu ZF, Plyusnin A (2010) Hantavirus infections in humans and animals, China. Emerging Infectious Diseases, 16, 1195-1203.

Zhang ZB, Cazelles B, Tian HD, Stige LC, Bräuning A, Stenseth NC (2009) Periodic temperature-associated drought/flood drives locust plagues in China. Proceedings of the Royal Society B: Biological Ences, 276, 823-831.

(责任编委：肖治术 责任编辑：黄祥忠) 